Int. J. Speleol. 7(1975), pp. 303-326.

\title{
The Invertebrate Fauna of Tropical American Caves, Part III: Jamaica, An Introduction
}

by

\author{
STEWART B. PECK*
}

\section{INTRODUCTION}

Jamaica, one of the smaller of the four islands of the Greater Antilles, is 150 miles long and 40 miles wide. About two-thirds of the island is underlain by limestones. This, together with an average 74 inch rainfall, has yielded an abundance of caves. Over 700 caves have been catalogued. Most of these occur in the White Limestone formation of Oligocene age, which reaches a thickness up 2,000 feet. The White Limestone is underlain by middle Eocene Yellow Limestone and is folded along an east-west axis. Fewer caves have been formed in Cretaceous limestone, gypsum deposits, subrecent raised coral rock, and post-Miocene limestone (Figure 1).

The Limestone plateau of central Jamaica is favoured for cave development because of its watershed which has a gentle gradient off the 1,500 to 3,000 feet high insoluable Central Inlier. This metamorphic ridge separates the limestone plateau into two main watersheds and the water running north or south disappears in numerous sinkholes and closed valleys in the extremely porous White Limestone (Figure 2).

The purposes of this paper are several: to bring together the scattered literature on the physical speleology of Jamaica; to bring together the little that has been published on Jamaican biospeleology; to give a general summary of the knowledge of the fauna resulting from my field work; and to make available descriptive data on the cave sites that have been biologically studied. A complete listing of the fauna of Jamaican caves and a synthesis of the ecology, evolution, and zoogeography of this fauna will be pubiished in a much later paper, after the many necessary taxonomic studies are completed.

\section{REVIEW}

There have been many publications on Jamaican karst and hydrology. General references on Jamaican caves, cave exploration, karst, and hydrology are those of Aley (1964), Ashcroft (1969), Read (1963), Smith, Drew and Atkinson (1972), Sweeting (1957, 1958), Versey (1972), White and Dunn (1962) and Zans (1956). Studies of specific caves or cave regions are Ashcroft et al. (1965), Brown and Ford

* Department of Biology, Carleton University, Ottawa K1S 5B6, Ontario, Canada. 


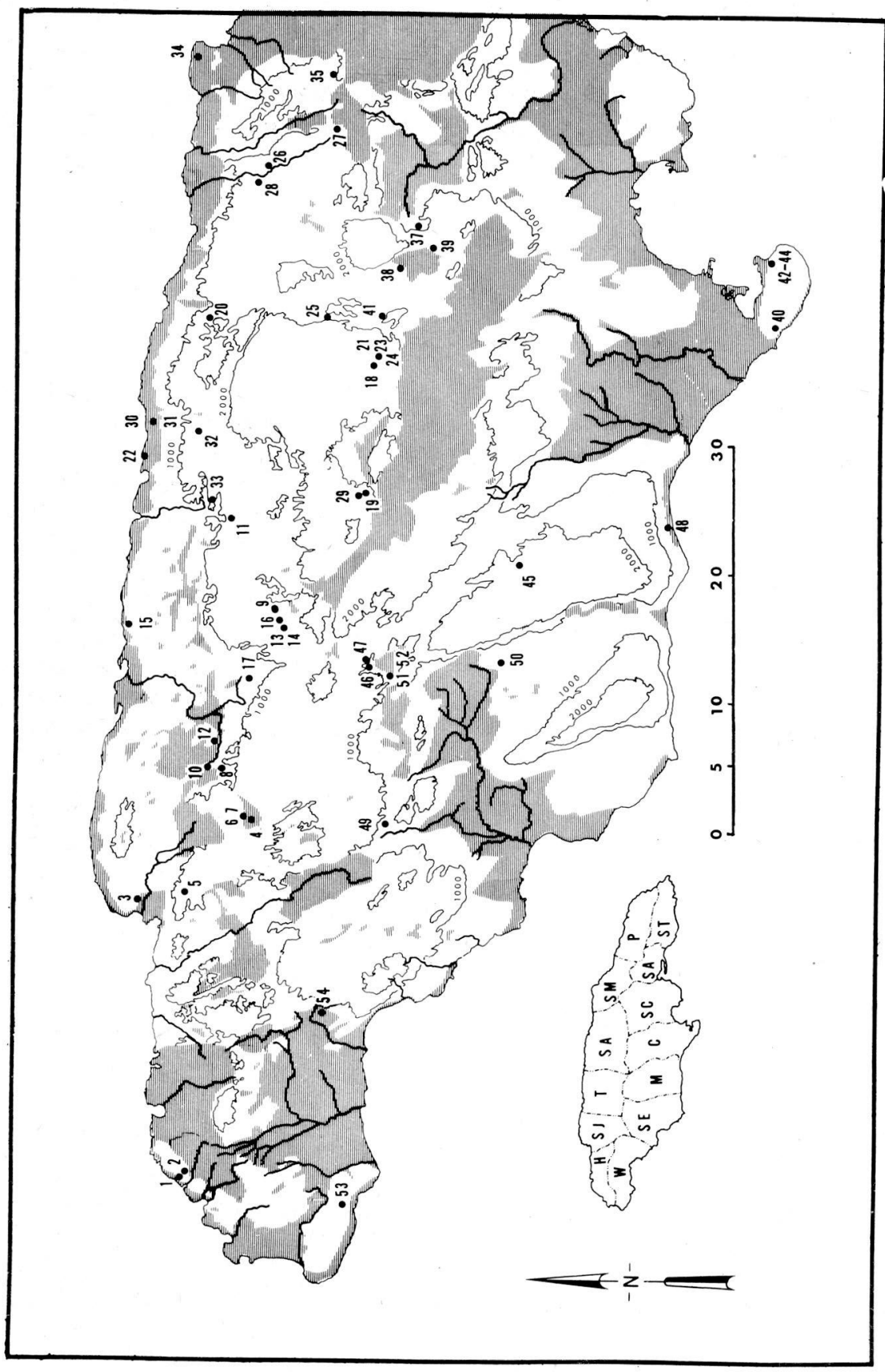


(1973), and Zans (1953, 1954). Atkinson (1969) reports on some five miles of surveyed cave passage in 35 caves. Livesey (1966) reports on 18 miles of surveyed passage in 47 caves. Fincham and Ashton (1967) report on about 20 caves, and include survey maps.

The Jamaican Caving Club, associated with the University of the West Indies, Mona, Jamaica, has done a considerable amount of cave exploration on the island. Alan Fincham (Department of Biochemistry, University of West Indies, Mona, Kingston 7, Jamaica) has been a prime organizer in the cave club and has compiled

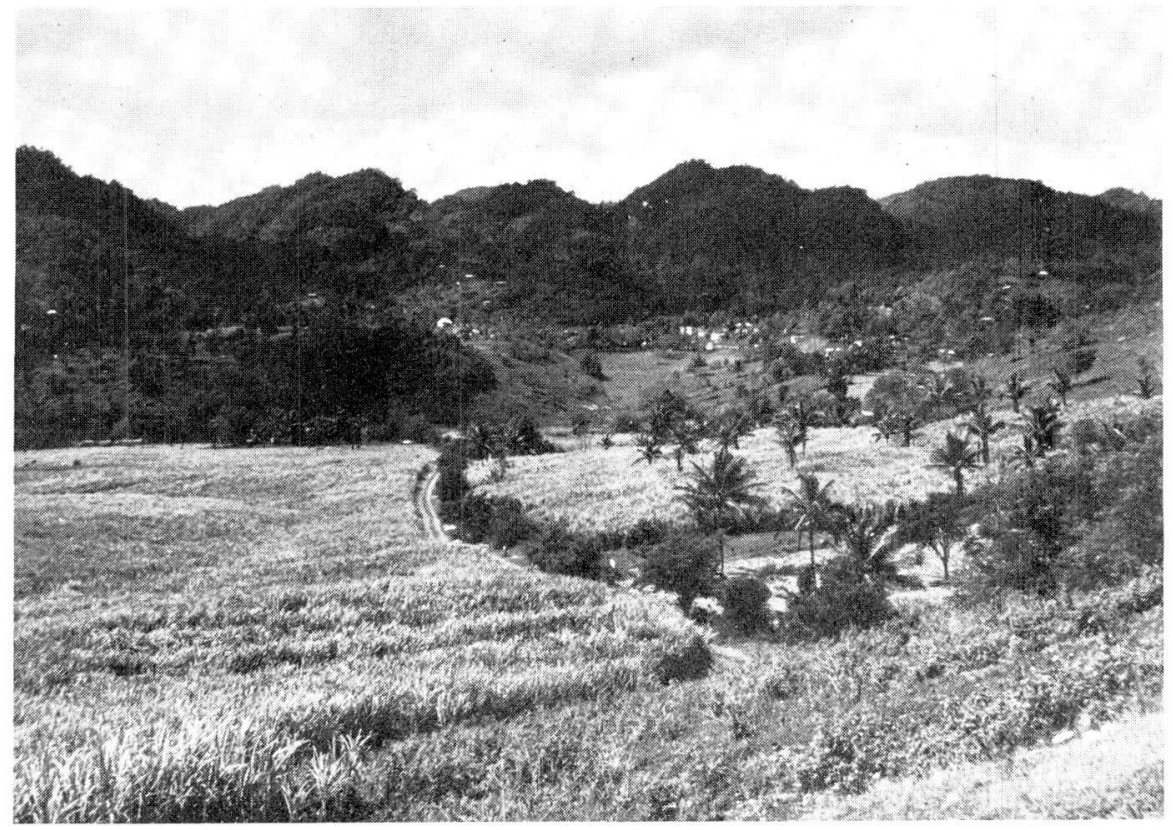

Fig. 2. Typical tropical karst landscape in Jamaica, showing an alluviated closed valley with sugar cane fields, and forested limestone "cockpit karst" hills.

Fig. 1. The western three-quarters of Jamaica, showing all the cave sites reported in this paper (except no. 36), in relation to topography, drainage, and geology. The contour interval is 1000 and 2000 feet. The numbers refer to the caves discussed in the text. The dark regions are generally insoluable volcanic or metamorphic rocks, or alluviated valleys. The open regions are mostly Cretaceous, Eocene, and Miocene limestones. The coastal caves in a dark background are in elevated Miocene, Pliocene, and Quaternary coastal formations. All major permanent streams and rivers are shown. The scale is in miles. Prepared from the 1:250,000 scale geology (1958) and topography (1966) base maps of the Geological Survey Department of Jamaica.

The lower left hand inset shows the locations of the Parishes into which Jamaica is divided. The Parish abbreviations are as follows, clockwise: H, Hanover; SJ, St. James; T, Trelawny; SA, St. Ann; SM, St. Mary; P, Portland; ST, St. Thomas; SA, St. Andrew; SC, St. Catherine; C, Clarendon; M, Manchester; SE, St. Elizabeth; W. Westmorland. 
most of the available information. The Jamaican geological survey has mapped many caves in relation to their guano-phosphate deposits.

General aspects of physiography, climatology and so forth will not be presented because these can be found in more general reference books, especially the Handbook of Jamaica published by the Jamaica Information Service, or in encyclopedias. Details relating to field localities which will be of help to Jamaican caving are in Wright and White (1969), Peck and Kukalova-Peck (1975), and Peck and Kukal (1975).

\section{THE VERTEBRATE FAUNA}

The first biological study of Jamaican caves was made by Anthony (1920a, 1920b), but he limited his work to mammals and vertebrate paleontology. Later reports on Anthony's cave collections are those of Koopman and Williams (1951), Williams (1952) and Williams and Koopman (1952). Several papers deal with Jamaican bats (such as Lewis, 1954) but Goodwin (1970) best unites the available bat data.

Fishes occur in some Jamaican caves. Guppies (Gambusia, perhaps gracilor) are in the flooded mouth of Wyslip Water Cave. Sleepers (Eleotris pisonis (Gmelin), Eleotridae or Gobiidae) have been captured in Jackson Bay Great Cave and Green Grotto Cave and were seen several times in Dairy Bull Cave. A blind fish, perhaps a brotulid, is supposed to be in Jackson Bay Great Cave (Ashcroft et al. 1965) but has not been captured and scientifically studied. This could be the fish that gave rise to early reports of Jamaican blind fish (Eigenmann, 1909: 188).

Eleutherodactylus frogs occur in some caves such as Jackson Bay, Cousins Cove number 2, and Monarva caves, and E. cavernicola Lynn is supposed to be found only in caves in Portland Ridge (Lynn, 1954).

\section{THE INVERTEBRATE FAUNA}

The only known flatworms from Jamaican caves are a blind, white species from rimstone pools in Carambie Cave. Nematomorphan (gordian) worms, undoubtedly cricket parasites, have been found in drip pools in three caves. The nematode fauna of cave soils and guano has not been studied. Oligochaetes have been found in soils and guano in some caves.

Pelecypod mollusks are restricted to a large population of Mytilopsis leucophaeata (Conrad) in brackish water in Green Grotto. Gastropod mollusks are commonly represented on guano by the circumtropical Subulina octona Bracquiere. The hydrobiid Potamophyrgus cf. corolla is abundant on rocks and wood near the surface of deep pools in Green Grotto. The stream in St. Claire Cave contains Physa jamaicensis C. B. Adams. Lage accumulations of shells, most commonly of Pleurodonte acuta, P. jamaicensis, Thelidomus acuta, Annularia pulchnim, Sagda (Sagdidae) and Dentellaria (Camaenidae), are found near the entrances of caves such as Idlewild, Worthy Park number 2, Dromilly, and Falling caves, but these snails have never been found living in the dark zones of any Jamaican caves. 
The onychophoran Plicatoperipatus jamaicensis (Grabam and Cockerell) has been found as an accidental in Moseley Hall Cave (Arnett, 1961). An undescribed troglobitic onychophoran (figure 3 ) is known from four specimens from Pedro Great Cave (Peck, 1975).

The Arachnida are well represented in Jamaican caves. Five species of Schizomidae, including Schizomus portoricensis (Chamberlin), have been found as troglophiles. The amblypygid Phrynus occurs in virtually every cave with crickets, upon which it preys. Spiders are represented by many families. The Dipluridae contains the common troglophile Accola lewisi Chickering and an undescribed troglobitic Accola. Psalistops (Barychelidae), Loxosceles caribbaea Gertsch, and Scytodes (Scytodidae) are commonly encountered troglophiles, as are Triaeris and Oonops (Oonopidae), Theotima minutissima (Petrunkevitch) and Ochyrocera (Ochyroceratidae). A troglobitic Theotima occurs in St. Claire Cave. Three troglobitic and three troglophilic Modisimus Pholcidae) are known. Gaucelmus cavernicola (Petrunkevitch) (Nesticidae) is a common and widespread troglophile. A troglophilic Maymena (Symphytognathidae) and Theridion rufipes Lucas (Therididae) are common. Pseudometa (Araneidae), Grammonota and Eperigona (Linyphidae), Corinna (Clubionidae), and Ctenus (Ctenidae) are occasionally encountered troglophiles. Zimiris (Prodidomidae) is represented by a troglobite in Falling and Worthy Park Caves.

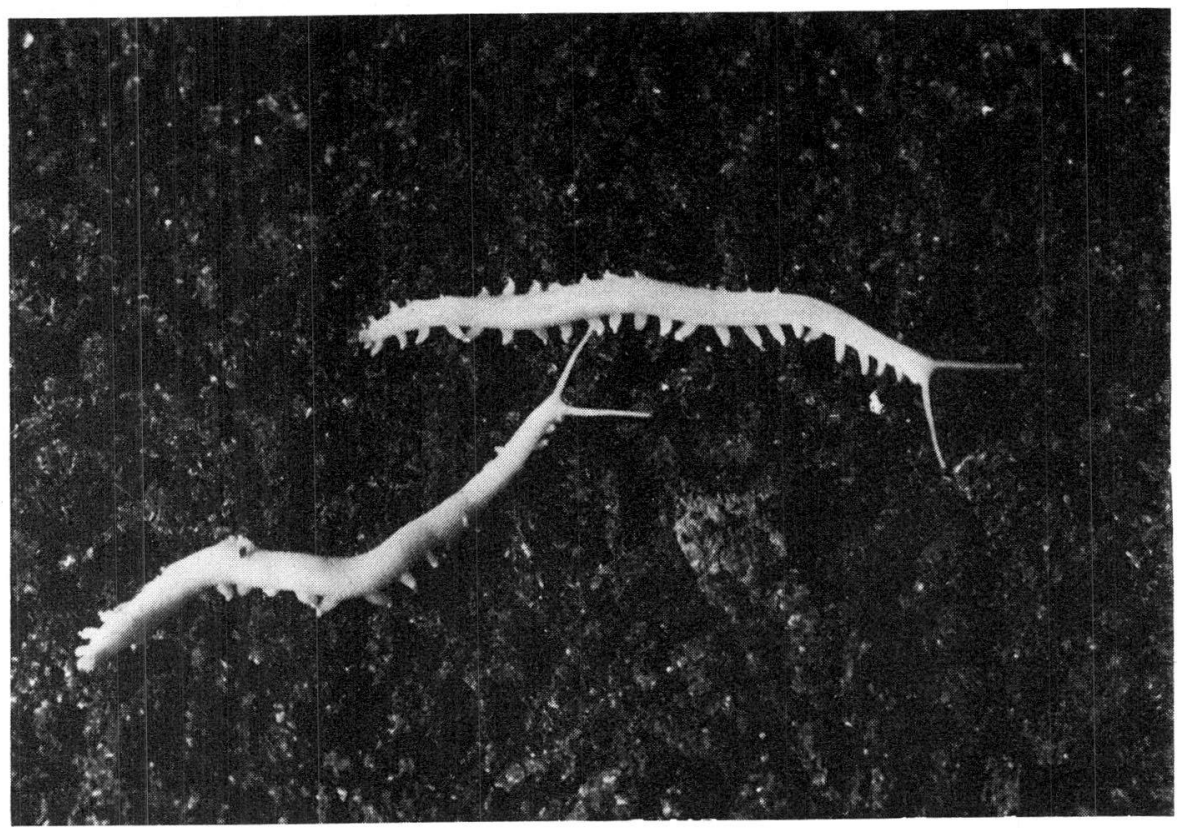

Fig. 3. An undescribed genus of troglobitic peripatid onychophoran. The only other caveevolved onychophoran is a peripatopsid from the Union of South Africa. 


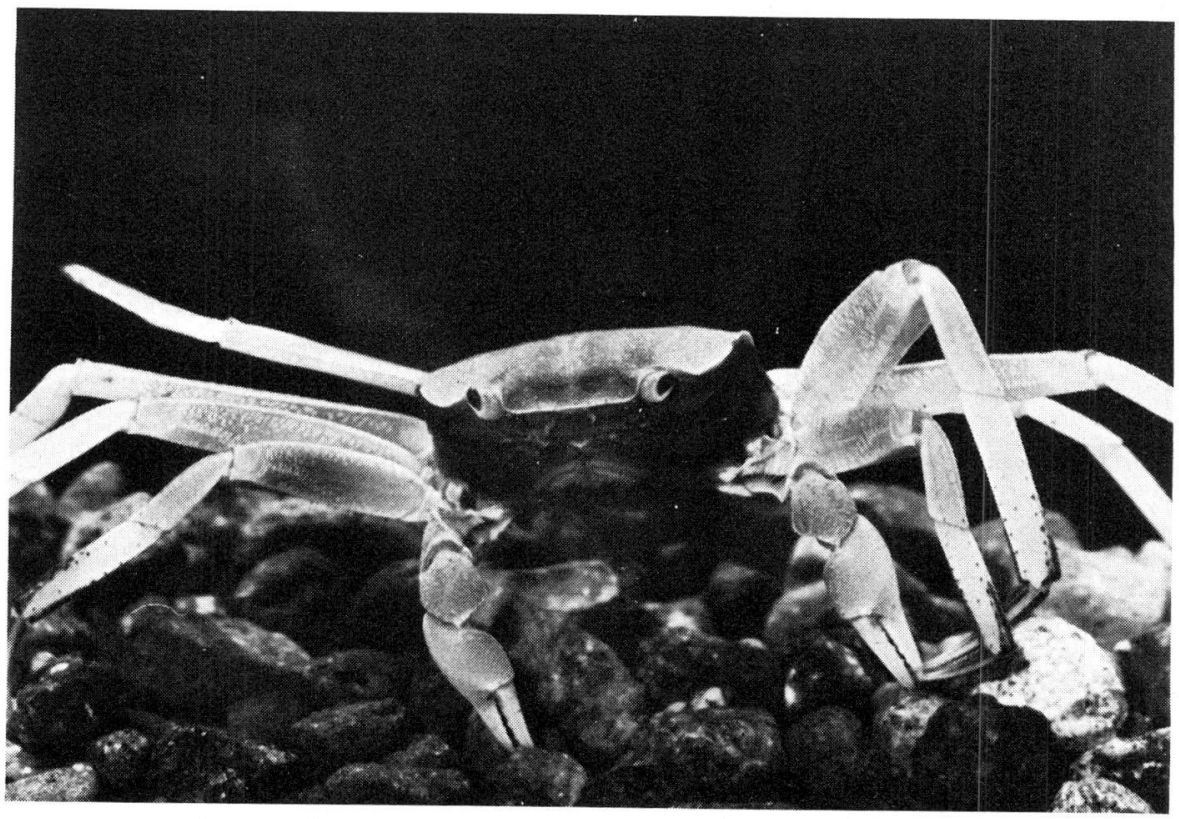

Fig. 4. Sesarma verleyi, a grapsid crab. Only in Jamaica have the grapsids entered freshwater, terrestrial, and cave habitats. This species has functional eyes but shows many other cave-specializations, such as depigmentation, appendage elongation, and cave-restriction; it may be justly considered a troglobite.

The Opilines are represented by three troglobitic phalangodids; Stygnomma fiskei and Cynortina pecki (Rambla, 1969), and by an undescribed species from Jackson Bay Cave. Troglophilic species are Stygnomma spinifera, Cynortina goodnighti and an unidentified but widespresd species of Nemastoma.

Pseudoscorpions are common in some guano and include Mesochernes, Lustrochernes and undetermined chernetids. Troglobitic species (Tyrannochthonius and Ideoroncidae) have been collected in Jackson Bay, Cousins Cove number 2, Drip, Maldon School, Carambie, and Wallingford Sinks Caves.

Many species of Acarina have been collected, mostly associated with guano, but no determinations are available.

Crustaceans include the trogloxenic or troglophilic crabs Gecarcinus ruricola (Linnaeus), Cardisoma guanhumi Latreille, Sesarma miersii Rathbun (all near the coast), and Sesarma bidentatum Benedict (inland); and the shrimps Atya innocous (Herbst), A. lanipes Holthuis, Xiphocharis elongata (Guerin-Meneville), Mecrobrachium carcinus Linnaeus, $M$. faustinum lucifugum Holthuis (1974) and M. heterochirus Wiegmann. Sesarma verleyi Rathbun (Figure 4) and the palaemonid shrimp Troglocubanus jamaicensis Holthuis are troglobites, even though the eyes are still 
present in the former species (Hartknoll, 1963-1964, 1964; Chace and Hobbs, 1969; Holthuis, 1963).

The amphipod Hyalella (cf. azteca) occurs in St. Claire Cave, and troglobitic Hadzia jamaicae Holsinger (1974) is in Jackson Bay Cave. Troglobitic Stygiomysis and Antromysis (Mysidacea) are known only from Jackson Bay Cave. Ostracods occur in drip pools and in very wet guano in several caves aiong with Copepoda (Elaphoidella).

Many species of terrestrial isopods occur, including the genera Clavigeroniscus, Cubaris, and Venezillio. At least one Claverigoniscus is troglobitic.

Scutigerid (Scutigera), cryptopid (Scolopocryptops, Cryptops, and Newportia), schendylid (Tanophilus?), henicopid and chilenophilid centipedes occur randomly.

The millipede fauna is diverse but no troglobites are known. Polyxenid millipedes inhabit dry caves with some organic matter. Glomeridesmus (Glomeridesmidae) Caraibodesmus pictus Loomis (Chelodesmidae), Peckfiskia cavernicola Loomis and Docodesmus (Chytodesmidae), Inodesmus jamaicensis Cook (Comodesmidae), Cyclodesmus hubbardi Cook (Sphaeriodesmidae), and eurydesmids, oniscodesmids, and trichopolydesmids occur in various caves and most frequently with guano.

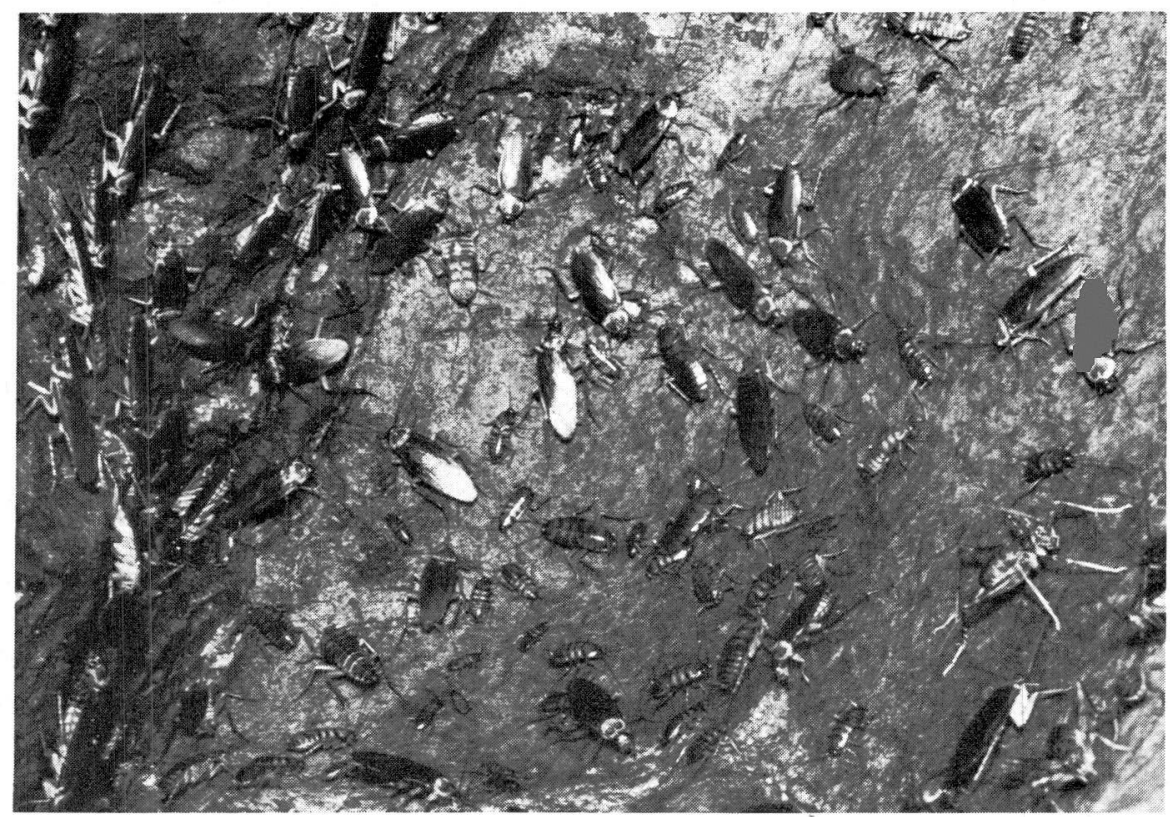

Fig. 5. An aggregation of Periplaneta americana roaches near guano in Oxford Cave. One cricket (Amphiacusta) is present. 


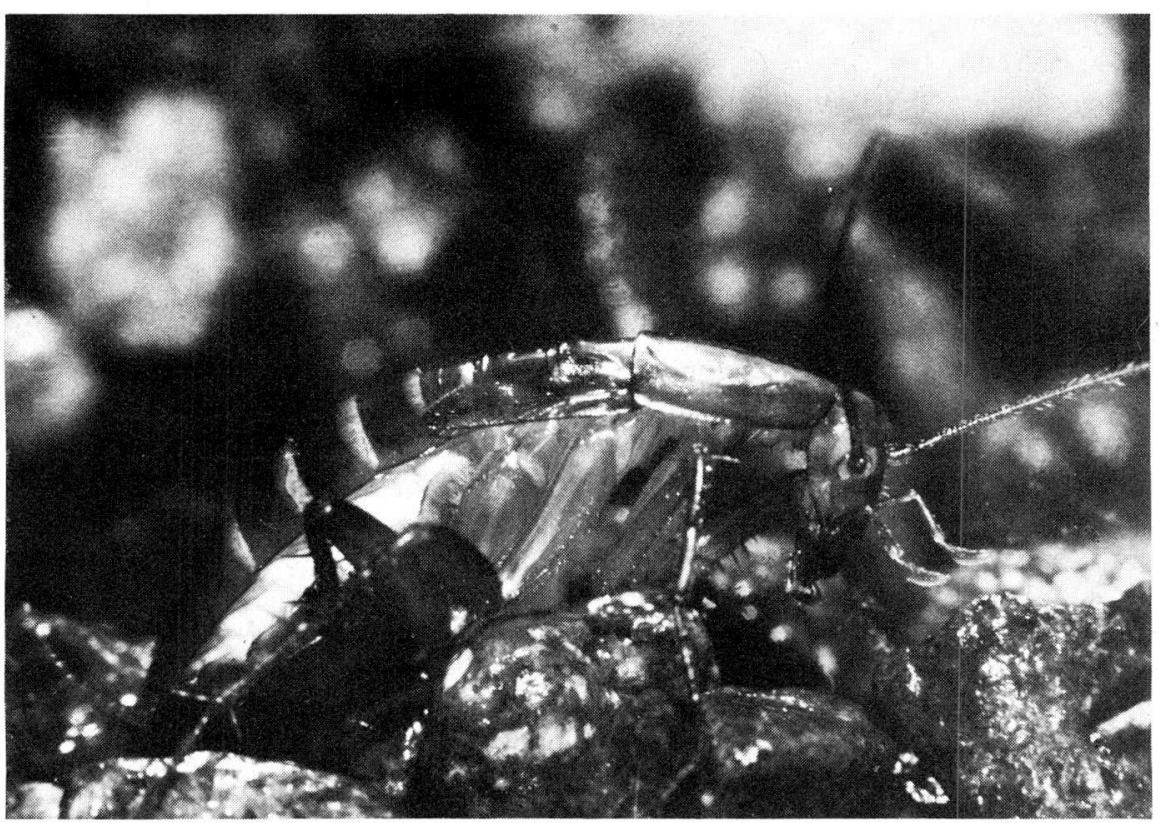

Fig. 6. This blind, apterous, troglobitic Nelipophyus roach, is found in many Jamaican caves, along with an eyed Nelipophygus, but generally in wet areas and not near large guano accumulations.

The collembola fauna includes the common and widespread troglophilic or trogloxenic Paronella, Xenylla, Isotomus, Metasinella, and perhaps a species in the Pseudosinella violenta group. One troglobitic Troglopedetes is known. Diplurans and thysanurans have been found in several caves, probably as troglophiles.

The Blattodea (cockroaches) include the blaberids Pycnoscelus surinamensis (Linnaeus), Epilampra, and Panchlora; the blattid Periplaneta americana (Linnaeus) is common in Winsor Great, Oxford an other guano caves (Figure 5); and the blatellids Ischnoptera and two species of Nelipophygus. One of the last is a troglobite, and is the only completely eyeless and apterous cave roach known (figure 6) except for two species of Speleoblatta from Burma.

Marava jamaicana (Rehn and Hebbard) is a dermapteran (earwig) living in some caves. Virtually every cave contains the gryllid cricket Uvaroviella cavicola Chopard (1928) (figure 7). It is interesting that the gryllid genus Amphiacusta, common in caves in other West Indian islands and on the tropical mainland, although present in Jamaica, does not occupy Jamaican caves.

Hemipterans are most commonly represented by Amnestus (Cydnidae). Microvelia argusta Drake and Maldonado occurs on cave streams. The reduviid (Emesinae) Ploiaria umbrarum M. A. Mc. A. y Maldonado is a common predator occurring on 
guano in several caves. An undescribed, blind and brachypterous cixiid bug from Jackson Bay Cave is a troglobite.

Many beetles are known from the caves. The carabid Colpodes cavicola Darlington (1964) is kno..n only from St. Claire cave but shows no cave specializations. Tachys and Perigona are additional troglophiles. Two troglobitic, blind scaratine Ardistomis carabids occur in Falling and Pedro Great caves. An undetermined dytiscid is in pools in St. Clair cave and Enochrus, Dactylosternum, Phaenonotum, and Omicrus are common hydrophilid troglophiles in guano. The leiodid Aglyptinus dimorphicus Peck (1972) occurs as a wingless form in caves on guano but as a winged form in Jamaican forests. Scydmaenids, pselaphids, ptiliids, histerids, and tenebrionids are occasionally found, usually in guano caves. The staphylinid $A$ theta is a common troglophile in bat caves. Other staphylinids, like Aleochara, Gyrophaena, and Proteinus, are infrequently found. The cerylonid Euxestus has formed a large population in guano in Brandon Hill Cave. The lamphrid Microdiphot cavernarum Barber is known only from one specimen from deep in Windsor Great Cave but does not show cave adaptation (Buck, 1959).

Lepidoptera are represented by the tineids Decadarchis and Tinea in almost every guano cave. The most common cave hymenopterans are ants (Formicidae)

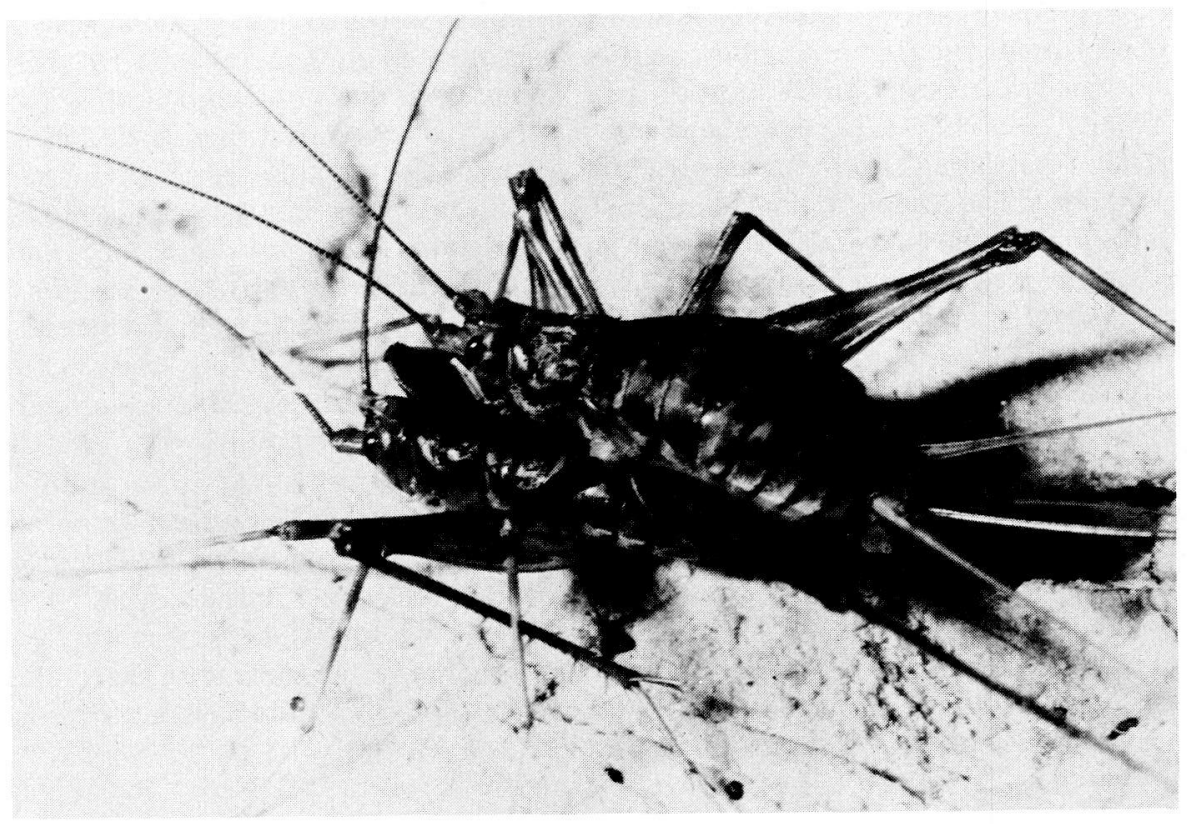

Fig. 7. The gryllid cricket Uvaroviella cavicola is known only from caves in Jamaica while crickets of the genus Amphiacusta which occur in caves elsewhere, occur in Jamaica only in non-cave habitats. The male, below, with raised tegmina, attracts the female for copulation by stridulating with his tegmina. 
which are common in guano caves and include Strumigenys, Tetramorium, and Odontomachus. The scelionid wasp Probaryconus and the cynipid wasp Pseudoeucoila probably parasitize cricket eggs and acalypterate Diptera larvae respectively.

Diptera are abundant and diverse. Shannonomyia nudipennis Alexander and Trentepohlia niveitarsis (Alexander) are tipulids occurring in Mocho Cave. The tipulid Polymera cavernicola Alexander was described from material caught deep in St. Clair Cave but has since been found at epigean sites at elevations ranging from 1750 to 4300 feet (Alexander, 1964). Most of the flies are associated with guano and include Dasyhelea (Ceratopogonidae), Drapetis pleuralis Melander (Empididae), Reichertella and Scatopse (Scatopsidae), Pholeomyia (Milichiidae), Leptocera (Sphaeroceridae), Conicera (Phoridae), Psychodidae, Sciaridae, and Dolichopodidae. The mycetophilid Orfelia, with a larva which forms a hanging web, is widespread but infrequent.

\section{SUMMARY OF THE INVERTEBRATE FAUNA}

As a result of our field work with the Jamaican invertebrate cave fauna, some 150 free-living macroscopic species are now known from this habitat. A complete and final list will probably contain many more species when all of our collections are fully studied. Most of these species are troglophiles associated with guano as scavengers or predators (figure 8). But, many species of troglobites are present, and these are mostly terrestrial. Since most of the troglobites are not yet described, the exact number is unknown, but is somewhere near 25 . The recognized troglobitic species are: a turbellarian flatworm, an onychophoran, six spiders, three phalangodid harvestmen, five pseudoscorpions, one grapsid crab (Sesarma verleyi), one palaemonid shrimp (Trogloocubanus jamaicensis), an amphipod (Hadzia jamaicae), an isopod (Clavigeroniscus), two mysidaceans (Stygiomysis and Antromysis), a roach (Nelipophygus), a cixiid bug, and two carabid beetles (Ardistomis). This may represent the largest density of troglobites on an island (Jamaica is $11,700 \mathrm{~km}^{2}$ ) in the American tropics. By contrast, somewhat smaller Puerto Rico $\left(8,800 \mathrm{~km}^{2}\right)$ has only two troglobites (Peck, 1974a, 1974b). The much larger island of Cuba $(105,000$ $\mathrm{km}^{2}$ ) has recently seen extensive biospeleological investigations by Cuban and Romanian workers and, although much of their work is yet unpublished, it appears that Cuba will have only a numerically similar troglobite fauna, with fewer terrestrial and more freshwater species (Nicholas, 1962; Orghidan, Jimenez, et al. 1973; Taboada, 1974).

As the cave faunas of the American tropics become better known, it is becoming more apparent that earlier generalizations, such as those about the lack of terrestrial tropical troglobites, will have to be revised.

\section{CAVE SITES STUDIED}

The caves reported on here were visited over a course of five trips to Jamaica: by S. 


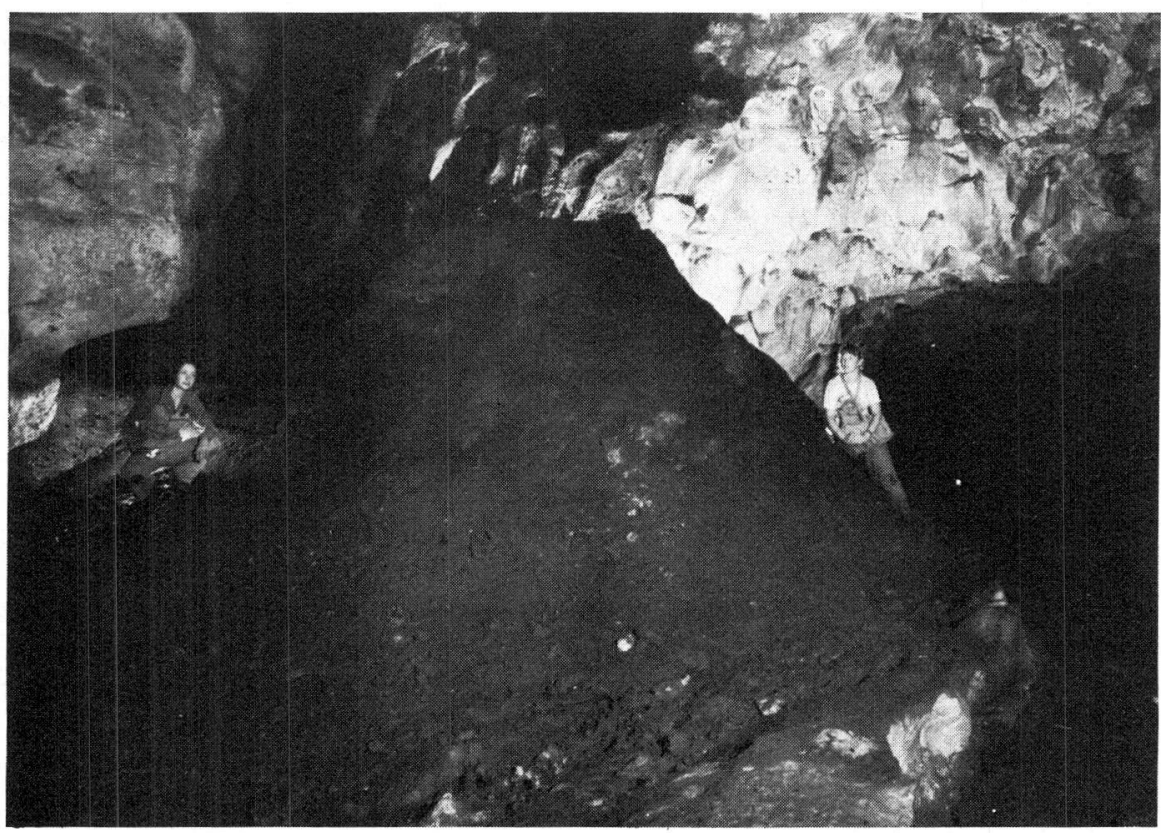

Fig. 8. A large accumulation of insectivorous bat guano in Oxford Cave. Guano mounds such as these are a focus for troglophilic arthropod scavengers and predators.

B. Peck and Alan Fiske in early 1968; by S. B. Peck and Jarmila Peck in late 1972; by Russel M. Norton and Roger Zimmerman in early 1973; by Russel M. Norton in late 1973; and by S. B. Peck, Jarmila Peck, Olga Kukal and Hana Kukal in mid 1974. These trips resulted in the location and biological exploration of 54 different caves and represent some three months of field effort for S. B. Peck alone, who made 70 visits to 46 caves. Russel M. Norton made 24 visits to 22 caves, many of which were also studied by S. B. Peck.

The distribution of the caves studied, in relation to non-limestone terrane, to rivers, and to elevation is given in figure 1. The following text discusses the caves in alphabetical order, grouped according to the Parish in which they are located. The caves are numbered in the text, and the same number is used for the caves in figure 1 .

For precise cave localities and for aid in prospecting for new localities, the 1:250,000 scale and 1:50,000 scale geologic and topographic maps are necessary. They may be obtained from the Jamaica Survey Department (the corner of Hanover and Charles Streets, Kingston), or Edward Standford Ltd., 12-14 Long Acre, London W.C.2. These maps record distances and elevations in miles and feet, which is why we use them in this report rather than the metric system.

In the following discussion, for each cave, the name is listed first, followed by its 
general location in airline map distance from a prominent feature named on the $1: 50,000$ maps (such as a town center or settlement), its map grid location, the approximate elevation of the entrance, the cave's approximate length, the initials of the lead biologist who studied the cave, and the dates of this study (to document population changes and the relative thoroughness with which the fauna may be known). The month is indicated in Roman numerals, a standard entomological procedure.

These are all of obvious value and easily understood except for the map grid locations which are helpful for locating the cave in the bush where the exact location is often extremely difficult to pinpoint. The grid reference is prefixed by a capital letter which refers to the letter assigned by the Jamaican Survey Department to the 1:50,000 series of topographic maps. Then comes a set of three numbers called "northings", the first two digits of which are found printed on the north and south sides of the indicated map. The third digit is that particular tenth of the north-south band determine $\mathfrak{d}$ by the first two digits. The last three digits are the "eastings", of which the first two digits are printed on the east and west sides of the indicated map, with the last (third) digit of this group being the particular tenth of the specified east-west band. By using this grid reference system, the cave can be located to roughly the nearest $1 / 10$ square mile. No more-accurate method is available for locating caves on Jamaican maps.

\section{BRIEF DESCRIPTIONS OF CAVES STUDIED}

Hanover Parish

1. Cousins Cove Cave number 1.1500 feet from coast, S of Cousins Cove. A 119 554. 50 feet elevation. 400 feet long. RMN, Nov., 1973; SBP, 31.viii.1974.

The large entrance chamber can be followed to the left to a high passage, from which large deposits of guano up to 40 feet in depth have been removed. This passage ends in a deep stagnant lake, 40 feet by 10 feet $\left(24^{\circ} \mathrm{C}\right)$, which fluctuates in level depending on local rains. To the right from the entrance chamber is a maze of dry passages, many excavated for guano. One fissure passage can be followed down to freshwater $\left(24^{\circ} \mathrm{C}\right)$. This section ends in a room with a skylight, from which descend large roots. The air temperature was $24^{\circ} \mathrm{C}$.

The guano fauna is not rich because few bats presently use the cave. No life was seen in the stagnant lake, except for psychodid fly larvae. Macrobrachium shrimp were seen, but could not be caught, in the fresh-water filled fissure. Fish are reported by the locals.

2. Cousins Cove Cave number 2. 0.4 mile SSE Cousins Cove. A 119 553. 160 feet elevation. 300 feet long. RMN, Nov., 1973; SBP, 31.viii.1974.

This is a small dry cave. The entrance drops to the left and ascends to a small skylight chamber and descends to a larger chamber with three other larger skylights. The cave has been mined for guano. Gypsum is present in fill in a side passage. The air termperature was $24^{\circ} \mathrm{C}$. The cave is reported to formerly have been 1800 feet long (a 600-foot-long E section, and a 1250 foot long SW section) with many bats, 
and a wooden stairway to wet lower levels. However, it seems that these E and SW sections were sealed about 1970 when the Land Commission put in a road over the cave. The now closed E section of the cave might be revisited if its skylight can be found and descended for its reported depth of 80 feet. The fauna is scant and poor in variety.

St. James Parish

3. Brandon Hill Cave. 0.9 miles E Montego Bay. C 233572.225 feet elevation. 419 feet long. RMN, 29.x.1973; SBP, 1.ix.1974.

From the entrance, a wide tunnel, with extensive sprumungs of guano, goes for about 300 feet. A side passage near the entrance has a 20 foot high working face of old guano excavations, and gives an interesting fill profile. Straight in front of the entrance a slope leads to a higher entrance and old dry guano diggings. Crawl holes are to the left of the entrance. The air temperature was $24.5^{\circ} \mathrm{C}$. A good rich guano fauna is present.

4. Maldon School Cave. In Maldon. C 271526.1244 feet elevation $500 f^{-n t}$ long. SBP, 3.ix.1974.

A steep entrance slope leads to a river, with a large chamber across it. The river can be followed either way in small scoured passages to sumps. The fauna was in the chamber in guano and flood debris. The temperature was $21.1^{\circ} \mathrm{C}$. A gypsum crust is present on the uper walls of the chamber.

5. Mocho Cave. 4 miles S Montego Bay. C 239548.1130 feet elevation. 427 feet long RMN, 30.v.1973.

The cave is a dry passage, up to 90 feet wide, with good formations, and bats. The invertebrate fauna was varied, and guano-associated.

6. Peterkin Cave. In Maldon. C 270 527. 1120 feet elevation. 1200 feet long. SBP, 3.ix.1974.

The eastern (Great) entrance sink leads to a tunnel opening into an elongated room, which descends at the far end to the underground course of the Tangle River. The river can be followed downstream to a sump and upstream to the rear entrance passage. Cave crabs and blind roaches are among the fauna, which is most diverse, but sparse, in the large room. The air temperature was $22.2^{\circ} \mathrm{C}$.

7. Rota Cave. In Maldon. C 272 528. 1100 feet elevation. 4000 feet long. SBP, 3.ix.1974.

The cave is almost entirely river passage of variable dimension and water depth. The water temperature was $21^{\circ} \mathrm{C}$ and the air $21.1^{\circ} \mathrm{C}$. The river reappears in nearby and more extensive Rota Sink Cave to the north, which we did not study. We studied only the Bottom Ground and Lower River passages. The fauna was sparse, being concentrated on flood debris and banks of guano high above flood level.

8. Spring Vale South Rising Cave. Spring Vale. C 285536.500 feet elevation. 150 feet long. SBP, 3.ix.1974.

This cave consists of a single large chamber, partly filled with muddy water, except for the twilight zone entrance slope. No fauna was observed except for accidentals.

Trelawny Parish

9. Carambie Cave. 0.35 mile (about 1900 feet) N of Spring Garden road junction. C 354 511. 1650 feet elevation. 700 feet long. SBP, 4.ix.1974. 
The entrance passage increases in size and turns into a handsomely decorated hallway, leading to a huge flowstone curtain, with a gigantic chamber behind it from which two passages proceed to other entrances. The temperature was $21.4^{\circ} \mathrm{C}$. The fauna is diverse and mostly associated with guano patches and organic debris. Blind flatworms are in one large rimstone pool with rotted bamboo.

10. Deeside River Cave. 0.25 mile SW Deeside. C 290 541. 600 feet elevation. 1100 feet long. SBP, 18.viii.1974.

The passage proceeds as a dry, formation-strewn gallery to a hole in a flowstone curtain. Beyond this a moist chamber ends on a 40 foot drop. Descent of this drop leads to a varied and richly decorated passage which reaches the river. The air temperature was $23.9^{\circ} \mathrm{C}$. In spite of the lack of organic matter, a varied but sparse assemblage of invertebrates was found before the 40 foot drop, including scydmaenid beetles.

11. Drip Cave. 1.5 miles SSW Stewart Town. F 392532.1280 feet elevation. 1000 feet long. SBP, 2.iv.1968, 25.viii.1974; RMN, 28.vii.1973.

The huge entrance sink descends into a large passage of guano-coated boulders. Abundant formations are present. At 500 feet in the cave a descent on the right wall goes to a lower level, floored with very wet guano. The upper and lower level again connect at the cave terminus. The air temperature was $20.2^{\circ} \mathrm{C}$. Cave fauna is rich and varied. Little active guano deposition is present.

12. Dromilly Cave. 2.25 miles SE Deeside, 0.4 miles N Dromilly.C 301. 537.390 feet elevation. 400 feet long. SBP, 28.viii.1974.

Tue cave, although not long, is an interesting and scenic complex of dripstone decorated chambers. A broad high chamber lies to the left of the back of the entrance chamber. A thick pavement of land snail shells leads to the right to a series of chambers with thick guano deposition. The air temperature was $23.7^{\circ} \mathrm{C}$. The fauna is guano-associated and includes staphylinid beetles, mites, tiniid moths, and collembola. Large numbers of web-spinning mycetophilid flies occur hanging under ledges in the flat floored room to the right of the eastern half of the cave.

13, 14. Harties Cave number 1 and number 2. 1 mile WNW Spring Garden, SW of Mouth River. C 352511.1750 feet elevation. Number 1 is 840 feet long and number 2 is 3470 feet long. SBP, 4.ix.74.

These caves are an interesting and varied complex of upper and lower passages. Number 1 has an upper level small stream, with cave crabs, and is easily explored. A guano coated ledge just inside the entrance of number 2 makes further entry hazardous. The fauna was varied but not concentrated. Guano was not seen except as a sprinkling, on which blind roaches were common, above the entrance canyon in cave number 2 .

15. Hope Gate Cave. 3.5 miles ESE Falmouth. C 340 574. 20 feet elevation. 700 feet long. RMN, 30.x.1973.

The cave is a labyrinth of passages, similar to Runaway Caves, but without water filled lower levels. Only a limited fauna was found.

16. Printed Circuit Cave. Spring Garden. C 352510.1750 feet elevation. 10,560 feet long. RMN, 30.iii.1973.

Several entrances to this complex system exist. The cave is diverse with old, 
large upper passages, and active lower stream passages. Additional details are given in Livesey (1966) an Brown and Ford (1973). A good faunal potential exists but not much was found in a-limited time.

17. Windsor Great Cave. Windsor, 9 miles S Falmouth. C 326528.375 feet elevation. 9770 feet long, SBP, 5.iv.1968; 26.viii.1974; RMN, 29.vii.1973.

The entrance tunnel opens into a huge breakdown chamber, over which one must climb and descend to the right cave wall. Following the left wall leads through deep guano to another collapse entrance. Deeper in the cave a series of very large chambers are encountered. The air temperature is $22.8^{\circ} \mathrm{C}$. Bat guano deposits are extensive. Side passages are few but present. The floor becomes more and more muddy and eventually meets a 35 foot clay pitch to the lower river level. The river may be followed upstream, emerging in a cockpit bottom, and the cave continues through a small hole in the oposite side. The fauna is guano-associated and troglobites are absent. Guano decomposition of the formations of limestone is extensive. St. Ann Parish

18. Brambribo Cave. 0.25 mile NW Douglas Castle, 4 miles NW Kellits. G 454 477. 200 feet elevation. 1000 feet long. SBP, 20.xi.1971; 18.viii.1974.

The cave is essentially a large tunnel with an irregular floor composed of breakdown blocks. Speleothems are abundant. At the back of the cave, an opening in a flowstone wall leads to a large chamber with a steeply descending guano slope, ending in a 40 foot diameter guano filled pool. Beyond the pool a passage is said to lead to another entrance. The pool was about a foot lower in the 1974 visit. Everything in the cave is thickly guano-coated. The air temperature was $22^{\circ} \mathrm{C}$ in 1972 and $23.4^{\circ} \mathrm{C}$ at the top of the lake room in 1974 . The large bat colony supports a rich guano fauna of snails, mites, flies, staphylinids, crickets, and spiders. No life was visible in the pool except for fly larvae.

19. Cave River Cave. 1.5 miles NNW Aenon Town. G 409482.2000 feet elevation. 18,000 feet long. SBP, 2.ix.1974.

We studied only the 950 foot long section of this extensive cave system between Holits Hole and Noisy Water resurgence. This is a large stream passage with generally shallow water, but it is subject to flooding. Crabs inhabit the stream waters and a mixed, but poor, terrestrial fauna is found on guano patches on slopes above flood level.

20. Chesterfield Cave. 4.5 miles S St. Anns Bay, 0.7 mile SW Higgin Town. F 475 536. 1800 feet elevation. 800 feet long. RMN, 27.ii.1973.

A spectacular descending entrance leads to an ascending boulder strewn chamber. To the right of the entrance a hole in boulders leads to a 45 feet deep pitch to a lower stalactite chamber. A limited fauna was found.

21. Cricket Cave. 0.25 mile E Douglas Castle. G 456 475. 2250 feet elevation. 300 feet long. SBP, 20.xii.1972, 18.vii.1974.

The cave is entered about 30 feet above the stream. Shortly inside, one descends to the stream and follows this upstream over breakdown to the end of the cave in breakdown. Cave crabs are present as well as a few other invertebrates on flood debris. Crickets are not abundant in spite of the cave name.

22. Dairy Bull Cave. 1.75 miles NE Discovery Bay. F 415569.10 feet elevation. 300 feet long. SBP: 22, 23, 24, 26, 28. viii, 1.ix.1974. 
The cave lies in a cemented Pleistocene coral reef deposit. A crawl to the east of the entrance meets a low seawater filled passage. To the west, a series of sand floored crevice passages are present. To the south, an upward squeeze leads into a 75 foot diameter chamber, with seawater on three sides. A small skylight is present. This chamber presents an interesting fossil assemblage in the ceiling. The pools, $27.2^{\circ} \mathrm{C}$, are inhabited by crabs, shrimp and fish, none of which are troglobitic. Crickets and amblypygids are also present.

23. Douglas Castle Cave. Douglas Castle. G 455 475. 2250 feet elevation. 100 feet long. SBP, 20.xi.1972.

The cave is a dry, much decorated chamber. No fauna was observed.

24. Falling Cave. 0.25 mile E Douglas Castle, 4 miles NW of Kellits. G 456475. 2250 feet elevation. 300 feet long. SBP, 20.xii.1972, 18.viii.1974; RMN, 3.xi.1973.

The cave is a single medium-diameter passage, which is profusely decorated. It is dry except for ceiling drips, and bats are absent. An interesting and varied fauna is present, including two species of troglobitic scaratine carabid beetles.

25. Ken Connell Hole. 0.75 mile N Bensonton, 7.5 road miles SW of Claremont. F 476491.1760 feet elevation. 900 feet long. RMN, 27.iii.1973; SNP, 19.viii.1974.

Just inside the 3 feet high, 10 feet wide entrance, a series of chimney descents takes one into a high but narrow canyon passage, which can be followed with difficulty to a terminal guano-covered room. The cave takes water in wet weather which flows down to the terminal room. Formations are present. The air temperature was $23.3^{\circ} \mathrm{C}$. The fauna is sparse and associated with guano and flood debris on the floor of the canyon passage. About 0.5 miles south of here, Hutchinson Hole, a simple shaft, 260 feet deep, lies just to the SE of the road. Hutchinson, the mad owner of Edinburgh Castle, is reputed to have dumped the bodies of his murdered victims into this sink. Sometimes locals switch the names of these two caves.

26. Lucky Hill Farm Cave. 0.5 mile NNE Lucky Hill. F 538519.850 feet elevation. 500 feet long. SBP, 25.vii.1972, 20.viii.1974; RWN, 31.iii.1973.

A steep descent on a slope of about 100 feet brings one to a pool with water pipes and a pump. Across the pool is a shaft to the surface with water pipes. The stream sumps here in debris. At one side of the pool, the upstream direction can be followed between formations into wading passage and two small chambers. The water was $22^{\circ} \mathrm{C}$ in 1972 , and $23.3^{\circ} \mathrm{C}$ in 1974 . Another surface shaft, to the south, was not descended but may go to other parts of the same cave system. Hartknoll (1963-1964, 1964) notes the cave as containing the troglobitic crab, Sesarma verleyi, and as the only known site for the Jamaican cave shrimp Troglocubanus jamaicensisHolthuis (1963). RMN obtained seven specimens of this shrimp. The other fauna is poor and scattered on guano patches and flood debris.

27. Moseley Hall Cave. 2 miles W Guys Hill. F 537492.1750 feet elevation. 800 feet long. SBP, 27.xii.1972.

The cave proceeds linearly through the hill. Formation areas are at both sides. The wide rooms have been mined for guano and some deposition is still taking place. The cave is generally dry, with an air temperature of $19.5^{\circ} \mathrm{C}$. The fauna is varied but not rich, except in a side passage in the cave middle. Some of the fauna has been discussed by Bengry (1953). 
28. Mount Plenty Cave. 1.5 miles NW Goshen. F 529521.1100 feet elevation. 530 feet long. RMN, 31 .iii.1973; SBP, 20.viii.1974.

The large entrance slopes down to a right and left hand passage. Both continue back to a series of chambers, the right hand side being more extensive. The discrete piles of guano might make this a good cave for the study of the ecology of the guano of insectivorous, frugivorous, and nectarivorous bats. The fauna was rich and varied, including several kinds of beetles. The air temperature was $22.2^{\circ} \mathrm{C}$.

29. Norwood Ratbat Hole. 2.6 miles NW of Cave Valley Crossroads. G 410487. 2200 feet elevation. 300 feet long. SBP, 2.ix.1974.

An impressive sink serves as an entrance. This is descended by a native laddercatwalk of bamboo, vines, and saplings. These are replaced yearly when the cave is mined for guano. The simple tunnel passage climbs breakdown and formations and descends to the guano room, with immense guano piles and an air temperature of $20.2^{\circ} \mathrm{C}$. This guano harbored immense numbers of fly larvae and the thickest concentration of mites we have encountered in any guano cave. A quantitative study of the guano fauna should prove interesting. No troglobites were found.

30, 31. Runaway Bay Caves and Green Grotto. 1.75 miles E Discovery Bay. F 420 566. 50 feet elevation. 4000 feet long. SBP, 29.xii.1972; 23. 24, 25, 26.viii.1974; RMN, March 1973.

This commercial cave is a complex labyrinth of dry, formation-clad passages with numerous skylights. The Green Grotto section has a pool of fresh-brackish water, $25.5^{\circ} \mathrm{C}$, which is commercially shown, and a more complicated side section of partly flooded bat chambers. The cave is discussed as Dairy Cave by White and Dunn (1962), and mammal fossils from the cave under this name are included in the papers by Koopman and Williams (1951) and Williams (1952). Mr. Jack Lewis, the cave owner, is agreeable to the study of speleological problems in the cave, but arrangements must be made ahead of time. Fauna is scarce in the dry sections except near guano and is most abundant on moist guano in the uncommercialized sections of Green Grotto. The lakes were sampled with minnow traps and contain crabs, Macrobrachium shrimp, and eleotrid (gobiidae) fishes.

32. Thatchfield Great Cave (Thatchfield Light Hole). 4.5 miles E Browns Town. F 444 546. 1450 feet elevation. 4000 feet long. RMN, 28.iii.1973, 24.x.1973.

The entrance is located on a cliff base, north of the Light Hole sink. A low passage leads to a large passage opening below the Light Hole. The passage may be followed east to a mud choke. A crawl over this leads to a very large descending tunnel proceeding for some 3000 feet to a shaft. The cave terminates shortly beyond the shaft bottom. Bats and guano and a guano fauna are present.

33. Thunder Cave. East of Stewart Town. Grid location not available. 1250 feet elevation. 150 feet long. SBP, 5.iv.1968.

The cave is a tube, about 150 feet long, sloping up on silt fill to a terminal chamber. There is barely a dark zone. A few bats are present. A few damp spots harbored small white isopods.

St. Mary Parish

34. Idlewild Caves. 3.8 miles on main highway east of road junction to Jacks 
River (at Oracabessa west town edge). K 582547.50 feet elevation. 100 feet long. SBP, 22.viii.1974.

The first cave, horizontal and at road level, is about 75 feet long, with only a twilight zone and bats. The second cave has a cenote-like entrance, sloping down to two small pools of fresh water on the south side. The water was $25^{\circ} \mathrm{C}$ and eyed Macrobrachium shrimp were seen in it but could not be captured. The third cave slopes steeply down between the rock wall and a talus-boulder fill. It does not reach water. Crickets are present here, and abundant land snails are cemented in a breccia on the wall.

35. Rock Springs Cavern. 0.5 mile E Pear Tree Grove. K 674489.1200 feet elevation. 2000 feet long. SBP, 21.viii.1974.

Swimming, with flotation gear, puts one through the small entrance opening into a large chamber with a waterfall at the far side. One can continue to work upstream in partly flooded passages and dry large-diameter upper levels through a variety of labyrinthine gallcries. Formations and vadose sculpturing are abundant. Gypsum crusts are present in the gravel-filled upper levels reached from Confusion Chamber. The fauna is varied. Macrobrachium and Xiphocharis shrimps are in the entrance pool, and the former and Atya shrimp are common deeper in the cave. The water temperature was $23.3^{\mathrm{C}}$. A very diverse guano fauna was associated with flood debris and with abundant but thin and wet coatings of guano. Tubificid worms and psychodid fly larvae were abundant in guano pools.

Portland Parish

36. Nonsuch Cave. 3 miles SW Port Antonio. M 750455.600 feet elevation. 250 feet long. RMN, November 1973.

The tourist literature describes this commercial cave as 500 yards long. It is a series of decorated rooms and passages, with an artificial rear entrance. Much fill was excavated to open the cave for tourism, and wall to wall concrete and gravel now floor the cave. No fauna was found. The limestone regions of eastern Jamaica, including the John Crow Mountains to the southeast, are the least known parts of the island. Superb cave potential should exist but only vague reports of caves and "roaring holes" are available.

\section{St. Catherine Parish}

37. St. Claire Cave. 1.5 miles SW Ewarton. G 520453.800 feet elevation. 9500 feet long. SBP, 7.iv.1968, 27.xii.1972.

From the entrance, descent is made over breakdown to a wide gallery, which eventually opens out over a large room. From this large room, the main passage continues to the east as a descending sand-floored tube, $23.5^{\circ} \mathrm{C}$, that carries intermittent flood water, to a lake which must be swum to enter the Lemon Ridge section of the cave and the other entrance. From the large room, a smaller passage doubles back under the entrance passage and proceeds to the southwest. Bats and guano fauna is concentrated here (air temperature $28^{\circ} \mathrm{C}$ ).

A partial map and description is in Zans (1954) and bats and invertebrates are covered by Lewis (1954) and Farr (1954) respectively. Rats occupy the bat caves and feed on them. A large population of house cats also occupies the caves, as 
evidenced by the abundance of their droppings in the entry passage and the several skeletons I found in the cave. These cats undoubtedly feed on bats and rats.

38. Swansea Caves. 2.4 miles N Worthy Park. G 497 464. 1500 feet elevation. 3840 feet long. RMN, 4.xi.1973.

The cave is essentially a single large but variable passage, occasionally containing flood waters. It is broken into four sections by cockpits. Bats and guano are present. The fauna is guano associated, but troglobites like Nelipophygus roaches are present.

39. Worthy Park Cave number 2. Worthy Park. G 504453.1250 feet elevation. 2300 feet long. SBP, 6.iv.1968, 26.xii.1972.

From an entrance boulder slope, a ladder drop of 30 feet leads to a chamber from which departs a spacious and fairly uniform cave passage. Throughout the cave length, it is pleasingly decorated, with intermittent pools which require wading. A rich fauna is found in the pools and on guano patches. Several troglobites are present, most notably the roach.

A bone breccia is present in the cave wall above and near the descent hole and should be of paleontological interest. Two other shorter caves (number 1 and 3) occur just south of this one but were not visited (Fincham and Ashton, 1967).

Clarendon Parish

40. Jackson Bay Great Cave. 1.1 miles SE Jackson Bay Village. H 472 303. 40 feet elevation. 10,000 feet long. SBP, 21-22.xii.1972; 2, 11, 15.viii.1974; RMN, November 1973.

The cave is a very complex gallery type of cave system. The outer rooms are partly flooded with brackish water which fluctuates with the tides. The air and water were $26^{\circ} \mathrm{C}$ in 1972 and $27.4^{\circ} \mathrm{C}$ and $26.2^{\circ}$ respectively, in 1974 . If the appropriate crawl can be found on the side of the largest lake room, this leads into a splendidly decorated, partially flooded tunnel. This section is the most scenic of any Jamaican cave. Beyond this a large upper series of chambers, which we did not study, end the cave. A complete description and map are in Ashcroft et al. (1965).

The fauna is rich. Troglophilic crabs occur in the outer rooms. A blind fish was captured but was eaten by a laboratory cat (Ashcroft et al. 1965). No other blind fish have been captured in Jamaica. The poor description suggests that the fish is a brotulid, of which two blind species are known in Cuba, and ono from Yucatan, Mexico. As long ago as 1909 (Eigenmann, 1909: 188) blind fish were said to occur in Jamaica, but they still elude capture for purposes of study and description. An Eleotris fish (Gobiidae) also occurs in the outer cave lakes. The invertebrate fauna contains many troglophiles, as well as troglobitic amphipods, two mysid crystaceans, harvestmen, pseudoscorpions, collembola, and cixiid bugs.

41. Pedro Great Cave. 0.6 mile SE Pedro River. G 476468.1700 feet elevation. 1500 feet long. SBP, 20.xi.1972; 17.viii.1974; RMN, 25.iii.1973.

The cave is a single large moist passage, heavily decorated, with much guano and no water. The air temperature was $21.5^{\circ} \mathrm{C}$ in 1972 and 1974 . A crawl is necessary to reach the last room, which was $22.2^{\circ} \mathrm{C}$ in 1974 . A map is in Fincham and Ashton (1967). The fauna is diverse and contains several troglobites, including eyeless scaratine carabid beetles and an eyeless onychophoran (figure 3). Some soil 
fauna is associated with the tree roots on damp soil in the dark zone of the entrance chamber.

42, 43, 44. Portland Ridge Caves. West of Mahoe Gardens on Portland Ridge. H 496 308. 120 feet elevation. 2000 feet long. SBP, 22.xii.1972, 15.viii.1974.

The lower caves are of a chamber type, from which guano has been mined. Formations are abundant. The caves are all dry with an air temperature of $27.2^{\circ} \mathrm{C}$. The fauna is scarce. Bat fossils from this cave are discussed by Williams (1952) and Koopman and Williams (1951). Many old wall inscriptions show that the caves were a popular spot with visitors over the past two centuries. The upper cave is a single, dry, large gallery, with a drop to a lower section that we did not visit.

\section{Manchester Parish}

4J. Abbey Cave. 2.5 miles S.W. Mandeville. D 364406.2300 feet elevation. 150 feet long.SBP24.XII.1972.

Easy descent into the sink leads to an old set of steps dating from the former show days of the cave. The large entrance tapers to a level passage, 15 feet wide, 30 feet high, and about 100 feet long, terminating in a side chamber. The temperature was $17.5^{\circ} \mathrm{C}$. The fauna was poor, containing only isopods, schizomids and spiders.

46. Coffee River Cave. Auchtembeddie. 1.5 miles N Oxford. D 333 476. 900 feet elevation. 9200 feet long. SBP, 4.ix.1968.

This extensive river cave was followed by us for only about 800 feet. The stream mostly occupies the entire passage width, over and through a jumble of boulders. Flooding can raise the waters by at least 8 feet. The fauna was of limited variety and mostly associated with banks of flood debris. Further description is in Livesey (1966), Brown and Ford (1973) and White and Dunn (1962, which refers to the cave as Princess Alice Cave).

47. Oxford Cave. Between Auchtembeddie and Oxford. D 332475.1000 feet elevation. 2300 feet long. SBP; 4, 8.iv.1968; 24, 30.xii.1972; RMN, November 1973.

The cave is a single passage, extensively decorated, which progressively increases in size towards the end. A large room and abundant guano are in the rear section. Drip water stands in the passage at the very end of the cave but has no fauna except for ostracods. The air temperature was $24^{\circ} \mathrm{C} 500$ feet in the cave, but is somewhat warmer in the bat chambers at the end. A map is given by Livesey (1966). Rats live in the cave, and we saw them feeding on invertebrates. A rich guano fauna is present, including crickets and roaches (Periplaneta) (Fig. 5). Several species of troglobites are present.

48. Wyslip Water Cave. Near Gut River. Grid location not available. Sea level. 75 feet long. SBP, 23.xii.1972.

The simple tunnel ony just reaches the dark zone. Fish and shrimp are in the lighted water at the cave entrance, but nothing was seen deeper in the cave. We could not find the nearby Wyslip Cave of White and Dunn (1962).

\section{St. Elizabeth Parish}

49. Duanwarie Cave number 1. 1.5 miles NW Ipswich. D 256476.800 feet elevation. 200 feet long. RMN, 29.x.1973. 
The cave is a dry passage, with a poor fauna. It is not 2800 feet long as has been reported.

50. Peru Cave. 2.5 miles NE Wilton. D 332428 . 270 feet elevation. 750 feet long. SBP, 23.xii.1972.

There are a number of sink-shaft or skylight entrances, only a few of which can be entered without special equipment. A labyrinth of high chambers is present. The cave is complex and confusing, with much guano, and many formations. Standing water was not seen but might have an interesting fauna if some could be found. The fauna was a standard guano-associated suite of invertebrates. No troglobites were found. This cave is the type locality for the spider Theridionexus cavernicolus Petrunkevitch (1928: 209), a synonym of Gaucelmus cavernicola (Gertsch, pers. comm.).

51, 52. Wallingford Cave and Wallingford Sink Cave. Wallingford, 1 mile N Balaclava. D 326466.900 feet and 700 feet elevation respectively. 200 feet and 1355 feet long respectively. SBP, 27.viii. 1974.

Wallingford Cave is a single dry tunnel, previously mined for guano, with formations. Wallingford Sink Cave follows the underground course of the river through large passage, over rapids and stretches of deep water, to a sump. This river resurges from Mexico Cave, a mile to the east and about 150 feet lower. A 100 foot long, low, but heavily decorated cave, lies in a small slot across from the houses at the road bend. It had no fauna. The fauna of Wallingford Cave was sparce because of its dryness. Wallingford Sink Cave contains shrimp and crabs in the river. Piles of flood debris supported troglophiles and troglobites, especially on upper ledges.

The fossil bones of five extinct species of mammals were removed by Anthony from "Wallingford Cave" from a cemented breccia-conglomerate. Since we saw such rocks only in Wallingford Sink Cave, we assume this is the cave from which the bones were recovered (Anthony, 1920a, 1920b; Koopman and Williams, 1951; Williams, 1952).

\section{Westmorland Parish}

53. Monarva Cave. 10 miles W Savanna-la-Mar, 0.75 mile ENE Brighton. B 102 483. 200 feet elevation. 1000 feet long. SBP, 30.viii.1974.

A small sink opening drops into a chamber, and the passage, up to 70 feet wide, descends by short drops for at least 100 feet. The passage takes water in storms. Large bat colonies are present, as well as much dryish guano. Oxygen deficiency affecting breathing rates and gasoline lanterns is evident in the lowest room we reached, but the cave continued in another descending, low hole. Standing water was not encountered. The temperature was $26.5^{\circ} \mathrm{C}$ in the middle of the cave and warmer in the lowest rooms. Crickets and roaches (Periplanetta) were the most abundant invertebrates.

54. Roaring River Cave. 7 miles NE Savanna-la-Mar. B 184503.250 feet elevation. 500 feet long. SBP, 29.viii.1974.

The cave is a series of high chambers. Several descending passages go to an underground branch of the surface stream. A large guano pool is present with mosquito larvae. A skylightshaft terminates the cave. The temperature was $24.4^{\circ} \mathrm{C}$. The fauna was limited to guano-associates, including ants and psychodid flies. 


\section{ACKNOWLEDGEMENTS}

Jarmila Peck, Olga Kukal, Hana Kukal, and Alan Fiske helped me in the field work. Russel M. Norton of Yale University, aided by Roger Zimmerman, collected specimens and contributed them to my study. Data on the caves visited by Norton was supplied by Alan Ficham. These people are all thanked for their help and aid. Bernard C. Lewis, Thomas Farr, and Georg R. Proctor of the Institute of Jamaica (Kingston) provided information and various kinds of assistance in Jamaica, including the use of the Institute Field Stations at Green Hills, White Marl, and Mason River. Mrs. Elsie Fenn's Guesthouse at Brownstown and the Discovery Bay Marine Laboratory were also used as bases for field work. Financial support for the 1968 work came from Evolutionary Biology Training Grant GB 7346 of the U. S. National Science Foundation, Prof. Reed C. Rollins, principal investigator, Harvard University. My two later trips, as well as those of M. R. Norton, were partially supported by my operating grants from the Canadian National Research Council. The Jamaican people themselves were of great aid in locating caves and generally made the field work memorable and pleasant. The taxonomic specialists who have helped with determinations are many and will be listed in a later paper. My wife, Jarmila, aided with the illustrations. Dr. John R. Holsinger is thanked for reviewing the manuscript.

\section{SUMMARY}

The scattered literature on the physical speleology and biospeleology of the West Indian island of Jamaica is brought together. As a result of recent field work, a summary of the Jamaican vertebrate and invertebrate cave is given. The invertebrate fauna is known to include some 150 free-living macroscopic species. These are mostly troglophilic scavengers and predators associated with guano accumulations. However, some 25 species, mostly terrestrial and undescribed, are known to be troglobites. This is one of the largest known assemblages of tropical troglobites. Brief descriptions are given for the 54 cave sites which have been biologically studied.

\section{RESUME}

Les diverses références bibliographiques sur la spéléologie physique et la biospéléologie de l'ile antillaise de la Jamaique ont été rassemblées. Une liste des Vertébrés et des Invertébrés de la Jamaïque récapitule les résultats d'un récent travail sur le terrain. Dans la faune des Invertébrés, on reconnait environ 150 espèces macroscopiques à vie libre, qui sont pour la plupart des troglophiles scatophages et prédateurs, associés aux dépôts de guano. Cependant, environ 25 espèces, principalement terrestres et pas encore décrites, sont connues comme troglobies. On se trouve là en présence de l'un des plus grands rassemblements de troglobies en région tropicale. 
De brèves descriptions sont données sur chacun des 54 sites de grottes qui ont fait l'objet d'études biologiques.

\section{LITERATURE}

Alexander, C. P. 1964. The Crane Flies of Jamaica (Diptera, Tipulidae). Bull. Inst. Jamaica, Sci. Ser \#14, $86 \mathrm{pp}$.

Aley, T. 1964. Origin and hydrology of caves in the White Limestone of north central Jamaica. Unpublished report available from Dept. Geography, University Calif., Berkeley, performed under ONR Contract ivonr 3656(3),Project NR 388 067, 29 pp.

Anthony, H. E. 1920a New mammals from Jamaica. Amer. Mus. Nat. Hist. Bull. 42: 469-475.

1920b. A zoologist in Jamaica. Natural History (Amer. Mus. Nat. Hist.), 20: 156-168.

Arnett, R. H. 1961. The Onychophora of Jamaica. Ent. News, 72: 213-220.

Ashcroft, M. 1969. Caves of Jamaica. Jamaica Journal, The Quarterly of the Institute of Jamaica, 3 (2): 32-36.

D. W. A. Hendricks, E. J. Herbert, D. P. Hodgson, E. Lodge, J. H. E. Perry and R. Swindells. 1965. Jackson's Bay Great Cave. Information, Bull. Sci. Research Council of Jamaica, 6(1): 13-19.

Atkinson, T. C. 1969. Report on cave exploration in Jamaica, 1967. J. British Speleol. Ass., 6(43/: 151-166.

Bengry, R. P. 1953. Cave notes, with special reference to Moseley Hall Cave. Nat. Hist. Notes, Nat. Hist. Soc. Jamaica, Kingston, 58: 165-167.

Brown, M. C. and D. C. Ford. 1973. Caves and groundwater patterns in a tropical karst environment: Jamaica, West Indies. Amer. J. Sci. 273: 622-633.

Buck, J. B. 1959. The Lampyrid Fireflies of Jamaica. Trans. American Ent. Soc., 85: 1-112.

Chace, F. A. and H. H. Hobbs, Jr. 1969. The freshwater and terrestrial Decapod Crustaceans of the West Indies with special reference to Dominica. U. S. National Museum Bull. 292. 258 pp.

Chopard, L. 1923. Description d'un Gryllide cavernicole de la Jamaique (Orth.). Bull. Soc. ent. de France, 1923: 84-87.

Darlington, P. J. 1964. West Indian Carabiae X. Three more species from Jamaica, including a new cave Colpodes. Psyche, 71: 181-182.

Eigenmann, C. H. 1909. Cave vertebrates of America. Carnegie Institution of Washington, Pübl. 104, $241 \mathrm{pp}$.

Farr, T. H. 1954. Arthropod life in the St. Clair Cave. Nat. Hist. Notes, Nat. Hist. Soc. Jamaica, 6: 146-147.

Fincham, A. and K. Ashton. 1967. The University of Leeds Hydrological Expedition to Jamaica 1963. Trans. Cave Research Group Great Britain, 9(1): 60 pp.

Goodwin, R. E. 1970. The ecology of Jamaican Bats. J. Mammalogy 51(3): 571-579.

Hartknoll, R. B. 1963-64. The freshwater grapsid crabs of Jamaica. Proc. Linn. Soc. London 175(2): 145-169.

1964. The cavernicolous decapods from Jamaica. Crustaceana 7(1): 78-79.

Holsinger, J. 1974. A new cavernicolous amphipod crustacean of the genus Hadzia (Gammaridae) from Jamaica, with notes on the distribution and taxonomic status of the genus. Ann. Speleol. 29(4): 647-655.

Holthuis, L. B. 1963. Two new species of freshwater shrimp (Crustacea, Decapoda) from the West Indies. Proc. Kon. Ned. Akad. Wetensch. Amsterdam (C) 66: 61-69.

1974. Subterranean Crustacea Decapoda Macrura collected by Mr. L. Botosaneanu during the 1973 Cuban-Roumanian biospeological expedition to Cuba. Int. J. Speleol. 6: 231-242.

Koopman, K. and E. E. Williams. 1951. Fossil chiroptera collected by H. E. Anthony in Jamaica, 1919-1920. Amer. Mus. Novitates, no: 1519, 29 pp. 
Lewis, C. B. 1954. The bat fauna of the St. Clair cave. Nat. Hist. Notes, Nat. Hist. Soc. Jamaica, 6: $143-146$.

Livesey, P. 1966. Full report of the 1965-1966 Karst hydrology expedition to Jamaica. Huddersfield, England, privately published, $67 \mathrm{pp}$.

Loomis, M. F. 1969. Millipeds from Jamaican caves. Florida Ent. 52(3): 141-145.

Lynn, W. G. 1954. Description of a new frog of the genus Eleutherodactylus from Jamaica, B.W.I. II. Washington Acad. Sci., 44 (12): 400-402.

Nicholas, Bro. G. 1962. Checklist of troglobitic organisms of Middle America. Amer. Midland Natur. 68(1): 165-188.

Orghidan, T. A. Nunez Jimenez, L. Botosaneanu, V. Decou, St. Negrea, and Nicasio Vina Bayes. 1973. Résultats des expeditions biospéléologique Cubano-Roumaines à Cuba. I. Editura Acad. Republicii Socialiste Romania, Bucuresti, 424 pp.

Peck, S. B. 1972. Leiodinae and Catopinae (Coleoptera: Leiodidae) from Jamaica and Puerto Rico. Psyche, 79: 49-57.

- 1974a. The invertebrate fauna of tropical American caves, Part II: Puerto Rico, an ecological and zoogeographic analysis. Biotropica, 6(1): 14-31.

- $\quad 1974 \mathrm{~b}$. Recent studies on the invertebrate fauna and ecology of sub-tropical and tropical American caves. Assn. Mexican Cave Studies Newletter 5(1): 30-38.

1975. A review of the New World Onychophora with the description of a new cavernicolous genus and species from Jamaica. Psyche, in press.

Peck, S. B. and J. Kukalova-Peck. 1975. A guide to natural history field localities in Jamaica. Studies of the Neotropical Fauna, 10: 105-116.

and O. Kukal. 1975. Jamaican caves and caving, a preliminary report. Canadian Caver, in press.

Petrunkevitch, A. 1928. Systema aranearum. Trans. Conn. Acad. Arts \& Sci., 29: 1-270.

Rambla, Maria. 1969. Cave harvestmen from Jamaica (Opiliones: Phalangodidae). Psyche, 76: 390-406.

Read, Ronald. 1963. Caves and cave men. Bull. Sci. Research Council of Jamaica, 4(2): 21-28.

Smith, D. I., D. P. Drew, and T. C. Atkinson. 1972. Hypotheses of karst landform development in Jamaica. Trans. Cave Research Group Great Britain, 14(2): 159-173.

Sweeting, M. 1957. Notes on the caves of Jamaica. Trans. Cave Research Group Great Britain 5(1): 1-11.

1958. The karstlands of Jamaica. Geogr. J., 124: 184-199.

Taboada, G. S. 1974. Sinopsis de la espeleofauna Cubana. Serie Espeleológica y Carsológica, no. 43. Inst. Geog., Acad. Ciencias Cuba, Habana. 65 pp.

Versey, H. R. 1972. Karst of Jamaica. in Herak, M. and V. T. Stringfield eds., Karst; Important Karst Regions of the Northern Hemisphere. Elsevier Publ. Co., Amsterdam, 445-466.

White, W. B. and J. R. Dunn. 1962. Notes on the caves of Jamaica. Natl. Speleol. Soc. Bull., 24(1): 9-21.

Williams, E. E. 1952. Additional notes on fossil and subfossil bats from Jamaica. J. Mammalogy, 33(2): 171-179. and K. F. Koopman. 1952. West Indian fossil monkeys. American Museum Novitates, no. $1546,16 \mathrm{pp}$.

Wright, P. and P. F. White. 1969. Exploring Jamaica, a guide for motorists. Andre Deutsch Ltd. London, $254 \mathrm{pp}$.

Zans, V. Z. 1953. The geology of the Moseley Hall Cave, Jamaica. Nat. Hist. Notes, Nat. Hist. Soc. Jamaica, 5: 156-163.

1954. The St. Clair cave in St. Catherine. Nat. Hist. Notes, Nat Hist. Soc. Jamaica, 6: 137-141.

1956. Caves and Sinkholes. in Handbook of Jamaica, Jamaica Information Service, Kingston, 18-19. 